Linda G. Levi

\title{
Family Searching and Tracing Services of JDC in the Second World War Era
}

\begin{abstract}
JDC HQ and local offices worked unstintingly to rescue and provide relief for Jews fleeing Nazi Europe. The organization's prior experience and relationships with local communities and international and local agencies were advantages that helped JDC galvanize aid where possible. Prior family tracing and search activities laid the groundwork for its extensive networking efforts in the Second World War era with US relatives of refugees in Europe who required assistance and survivors searching for their families. These efforts helped reunite families. JDC and Central Location Index staff pursued family search with expertise, empathy, and a sense of personal and communal mission, collaborating with the IRC and UNRRA. Discussions beginning in 1947 about establishing a centralized International Tracing Service made CLI and JDC leaders uneasy. Would a more distant and standardized ITS have the necessary knowledge, expertise, and sense of urgency? Nevertheless, JDC leaders cooperated with efforts to establish the IRO International Tracing Service. Beginning in August 1948, JDC began closing its tracing bureaus and transferring records to the ITS. In May 1949, the CLI ceased operations.
\end{abstract}

\section{Introduction}

The American Jewish Joint Distribution Committee (commonly known as "the Joint" or JDC), established in 1914 in response to the devastation caused by the First World War, began rescue and relief work in Europe at that time and continued its involvement both in Europe and in a total of 70 countries across the globe during the interwar years. Thus, even before the rise of Nazism in Germany, JDC had an understanding of the local context in Europe and had established contacts and relationships with Jewish communities and other NGOs on the ground in Europe and elsewhere. This experience proved useful as the JDC became deeply involved in rescue and relief programs before, during, and after the Second World War. JDC's activities included family searching and tracing services from the perspective of seeking out US-based family members to assist their European relatives with affidavits and other emigration assistance, to assist worried overseas relatives seeking news on the whereabouts of family in Europe during and after the war, and to help survivors with their search for relatives in

Ә OpenAccess. (C) 2020 Linda G. Levi, published by De Gruyter. (cc) BY-NC-ND This work is licensed under the Creative Commons Attribution-NonCommercial-NoDerivatives 4.0 License. https://doi.org/10.1515/9783110665376-005 
the period immediately after the war. JDC's network of offices in Europe and elsewhere communicated closely on such family searches and worked closely with the Central Location Index, which it helped to establish in New York in 1944, and with UNRRA's Central Tracing Bureau and later the International Tracing Service when it was established in 1948.

\section{Context and Background}

The conflicts and pogroms that took place during and after the First World War brought disease, famine, and dislocation to hundreds of thousands of Jews in Central and Eastern Europe, especially in Poland. In response, JDC provided food to hundreds of towns and villages, dispatched delegations of doctors, public health experts, and social workers, set up soup kitchens, rebuilt hospitals, and opened orphanages. To foster independence, JDC sponsored a network of self-help Jewish organizations, cultural and religious institutions, and vocational training centers.

During the First World War and in the years following the war, JDC was extensively involved in networking activities between families in the US and relatives in Europe. During the war years, family members overseas were no longer able to send remittances to their relatives in Eastern Europe. JDC established a transmission bureau ${ }^{1}$ whereby they could ensure that financial assistance from relatives in the US and elsewhere deposited with JDC would reach family members impacted by the war in Europe. This relationship worked in both directions in that JDC field workers in Europe would transmit requests for assistance from family in Europe to relatives in the US via the JDC. Similarly, JDC worked with Landsmanschaften in the US that sought to get funds to their landsmen in Europe.

During the interwar period, JDC was assisting vulnerable Jewish communities worldwide. As such, it had established on-going relationships with Jewish communities in 70 countries around the world. Thus, given its widespread presence across the globe, JDC was uniquely able to help trace relatives during the Second World War era. ${ }^{2}$

1 JDC Archives, Records of the New York office of the American Jewish Joint Distribution Committee, 1914-1918, Folder \#3.2, Minutes of the Executive Committee, 16.11.1916; http://search. archives.jdc.org/notebook_ext.asp?item=165.

2 For further background, see Avinoam Patt, Atina Grossmann, Linda G. Levi, and Maud S. Mandel (eds.): The JDC at 100: A Century of Humanitarianism, Detroit: Wayne State University Press, 2019, chapters 1-3. 


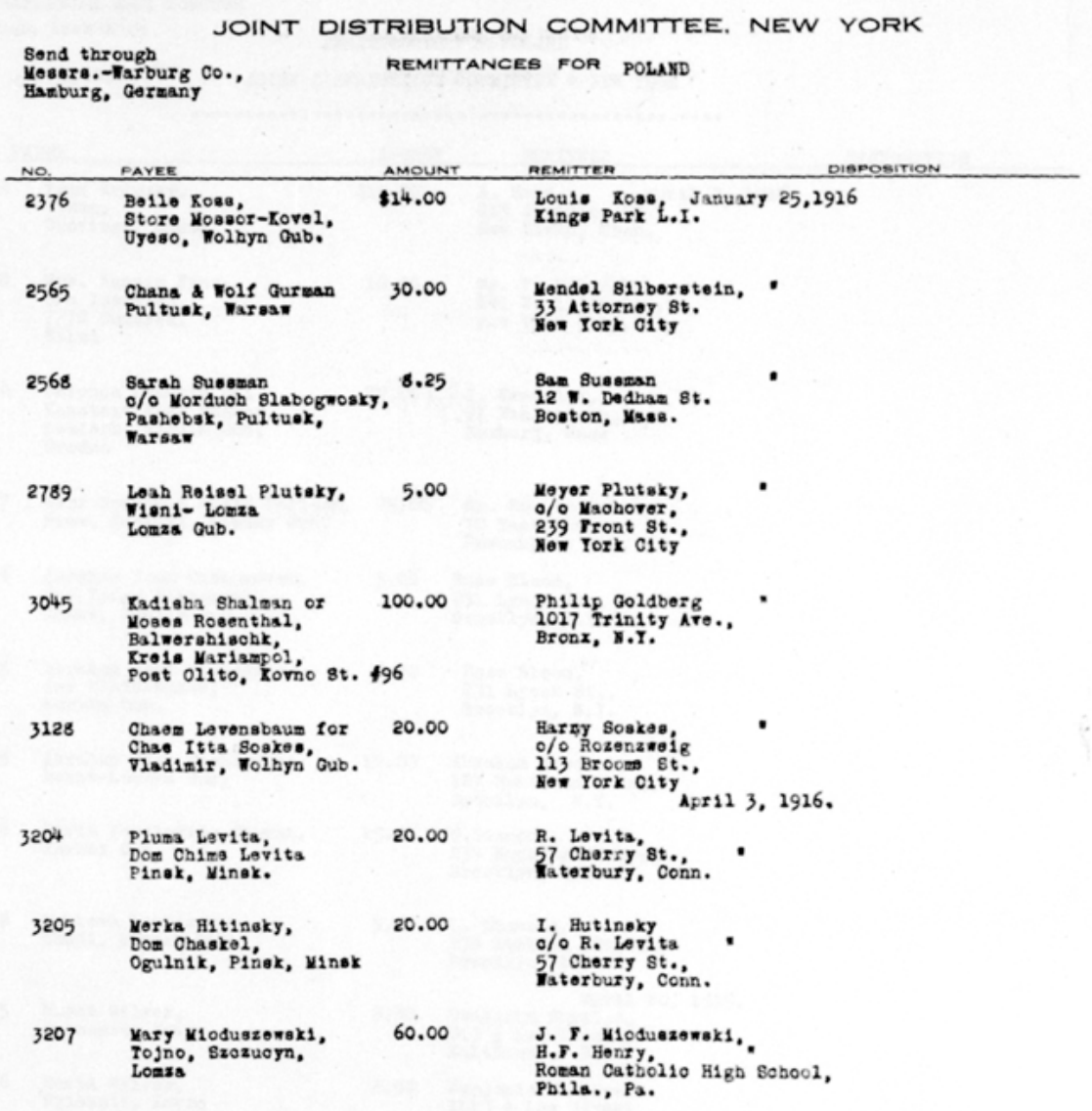

Fig. 1: List of remittances for Poland, 25.1.1916 (JDC Archives, Records of the New York Office of the American Jewish Joint Distribution Committee, 1914-1918, folder \#36, Remittances for Poland, 1915-1917; http://search.archives.jdc.org/notebook_ext.asp?item=3303)

\section{JDC Efforts during the Second World War Era}

\section{Germany}

With its overseas headquarters based in Berlin, JDC had a close vantage point to view the early impacts of the Nazi party on German Jewish life. In 1933, the organization moved its headquarters operations to Paris in response to a threat against its office. However, a small office was retained in Berlin, and close rela- 


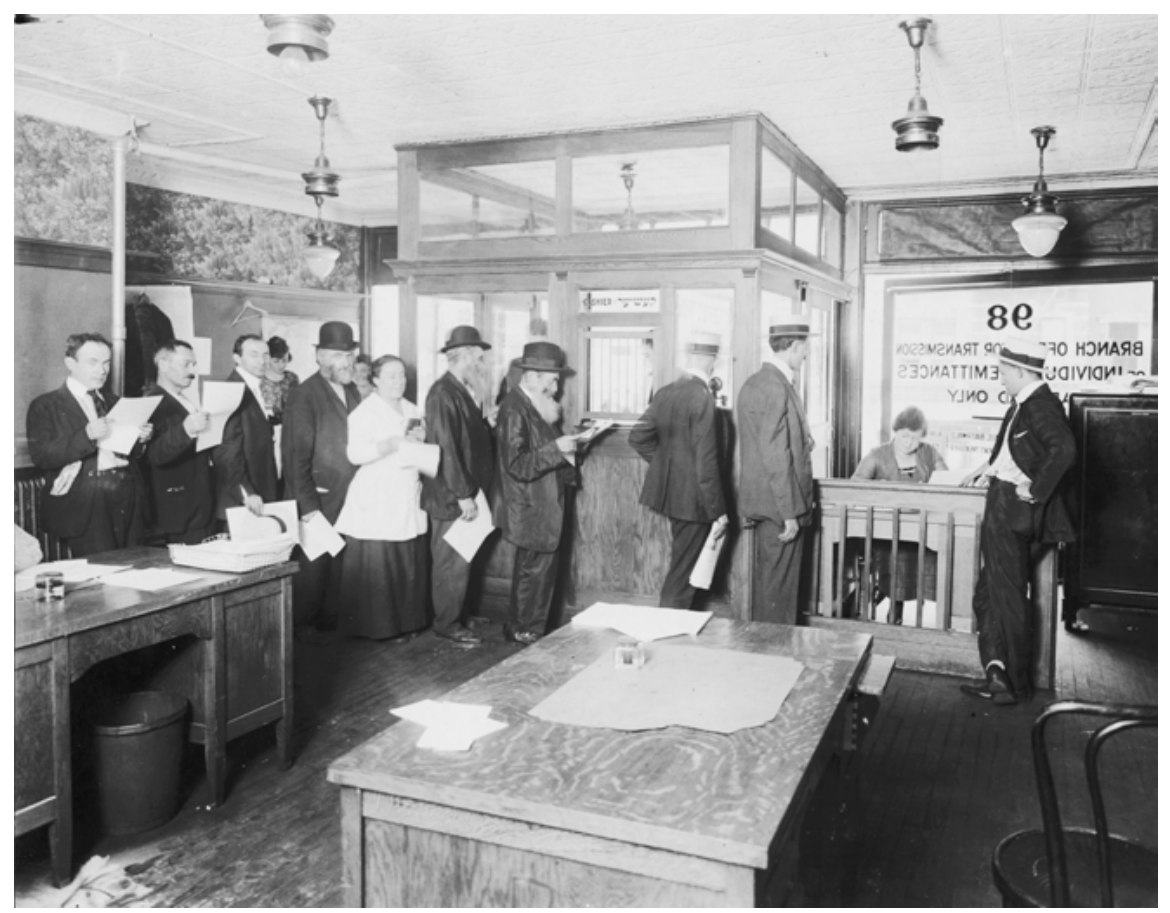

Fig. 2: People line up in a JDC transmission office to send funds to family abroad, New York, c. 1917 (JDC Archives Photograph Collection, NY_03488)

tions with the Jewish community continued. JDC provided assistance during the 1930s as the German Jewish community responded to the Nuremberg Laws and the restrictions placed on Jews. It also assisted with the development and funding of retraining programs as Jews were excluded from certain professions, established more Jewish schools (as Jewish children were no longer accepted in public schools), funded welfare programs for the needy, and provided emigration assistance.

As Jews began to leave Germany and Austria, JDC worked to identify countries that would accept Jewish refugees either on a temporary or permanent basis. JDC archival records include many lists of people assisted during this period; these lists, which date from the late-1930s and extend throughout the Second World War, were often useful in tracing family members. Lists such as the passengers of the St. Louis and the countries to which the 907 stranded passen- 
gers were taken after being denied entry into $\mathrm{Cuba}^{3}$ or lists of over 18,000 refugees assisted in Shanghai ${ }^{4}$ are but two examples of the thousands of such lists within the organization's text collections.

JDC provided relief assistance to Polish Jews who were expelled from Germany between 1938 to 1939 to the no-man's land areas at the border with Poland. These efforts were led by Emanuel Ringelblum, who was already serving on the staff of the JDC Warsaw office. A 127-page list from 1938 and 1939 with the names of 1,542 refugees assisted in Zbaszyn and in other no-man's land towns (such as Kolomyja, Jaroslaw, Stanislawow, Drohobycz, Jablonow, and others) is included in the JDC Archives and has been indexed in the JDC Archives Names Index. ${ }^{5}$ These lists include the names and addresses of relatives in the US so that JDC New York could contact family members to inform them of the whereabouts and the needs of their relatives who had been expelled from Germany.

\section{Poland}

On September 1, 1939, Nazi Germany invaded Poland, and the Second World War commenced. Of the 3.3 million Jews living in Poland in 1939, several hundred thousand fled eastward into Soviet territory, but the vast majority found themselves under Nazi rule. The economic impact was immediate: Jewish enterprises were destroyed, property was confiscated, and Jews were subjected to forced labor. Food shortages were acute, and disease was rampant, especially after the establishment of ghettos in Warsaw, Lodz, and elsewhere.

Thousands of Polish Jewish refugees fled to Vilna, where JDC, working with the local community, assisted refugees with food kitchens, refugee assistance, and emigration including funding passage on trains across the Soviet Union to the Asian areas and to Vladivostok and from there to Japan and Shanghai. One JDC Archives list includes names of over 9,000 Polish Jewish refugees

3 JDC Archives, Records of the New York Office of the American Jewish Joint Distribution Committee, 1933-1944, Folder \#384, MS St-Louis Passengers and their Distribution, 18.7.1939; http:// search.archives.jdc.org/notebook_ext.asp?item=444078.

4 JDC Archives: see "Lists from the Nazi Period and Its Aftermath" at https://archives.jdc.org/ our-collections/names-index/lists-in-the-names-index/.

5 JDC Archives, Records of the New York Office of the American Jewish Joint Distribution Committee, 1933-1944, folder \#879, Lists of Refugees at Zbaszyn, 1938-1939; http://search.archives. jdc.org/notebook_ext.asp?item=509854. 


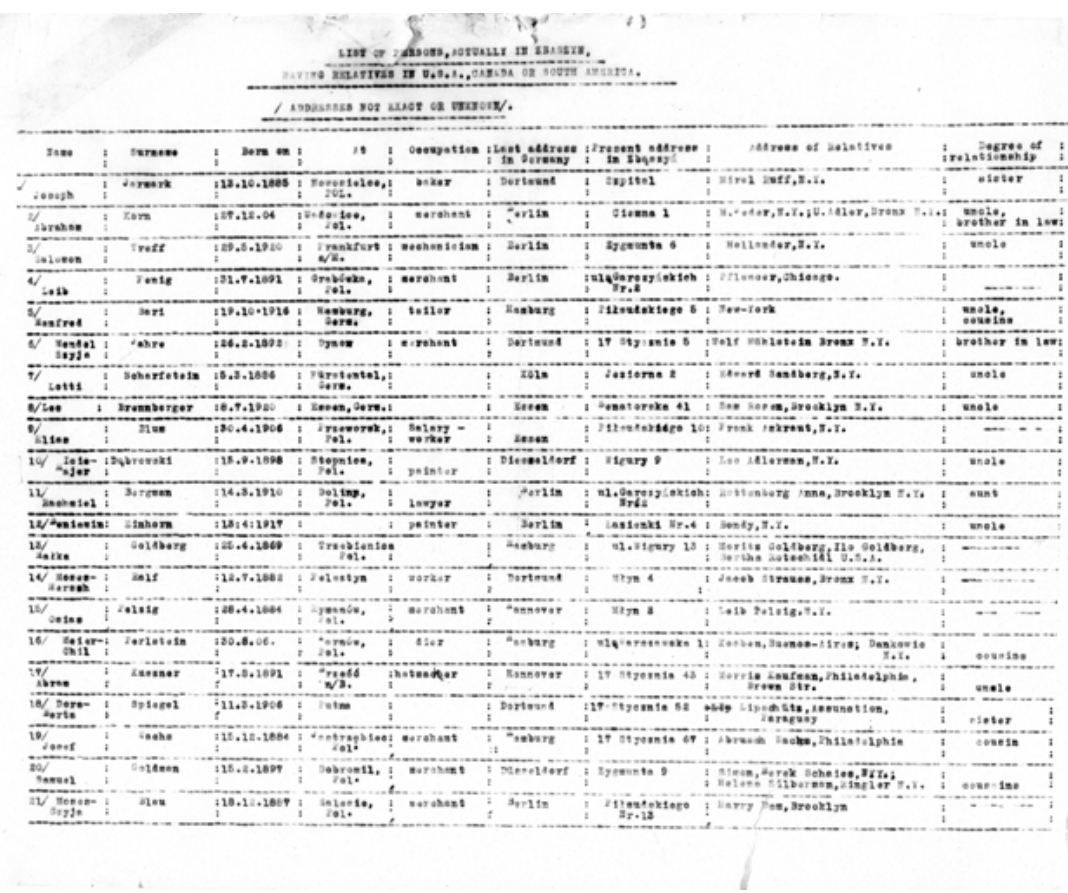

Fig. 3: List of Jewish refugees in Zbaszyn having relatives in the US, Canada, or South America (JDC Archives, Records of the New York Office of the American Jewish Joint Distribution Committee, 1933-1944, folder \#879, Zbaszyn, 1938-1939, Lists of Refugees at Zbaszyn; http:// search.archives.jdc.org/notebook_ext.asp?item=509854)

being helped by JDC in 1940 in Vilna. ${ }^{6}$ The JDC Archives includes 73 lists detailing 6,300 names and addresses of recipients of free parcels sent to Polish Jewish refugees who fled east to the Soviet Union. ${ }^{7}$

6 JDC Archives, Records of the New York Office of the American Jewish Joint Distribution Committee, 1933-1944, folder \#876, Vilna Refugees 1940, List of Refugees, 4.2.1940; http://search. archives.jdc.org/notebook_ext.asp?item=509518.

7 JDC Archives, Records of the New York Office of the American Jewish Joint Distribution Committee, 1933-1944, folder \#428, Lists of JDC Beneficiaries Being Sent Packages in the USSR \#1-73, 27.6.1944; http://search.archives.jdc.org/notebook_ext.asp?item=449962. For further background, see Atina Grossmann: “Joint Fund Teheran': JDC and the Jewish Lifeline to Central Asia”, in Avinoam Patt, Atina Grossmann, Linda G. Levi and Maud S. Mandel (eds.): The JDC at 100: A Century of Humanitarianism, Detroit: Wayne State University Press, 2019, $205-244$. 


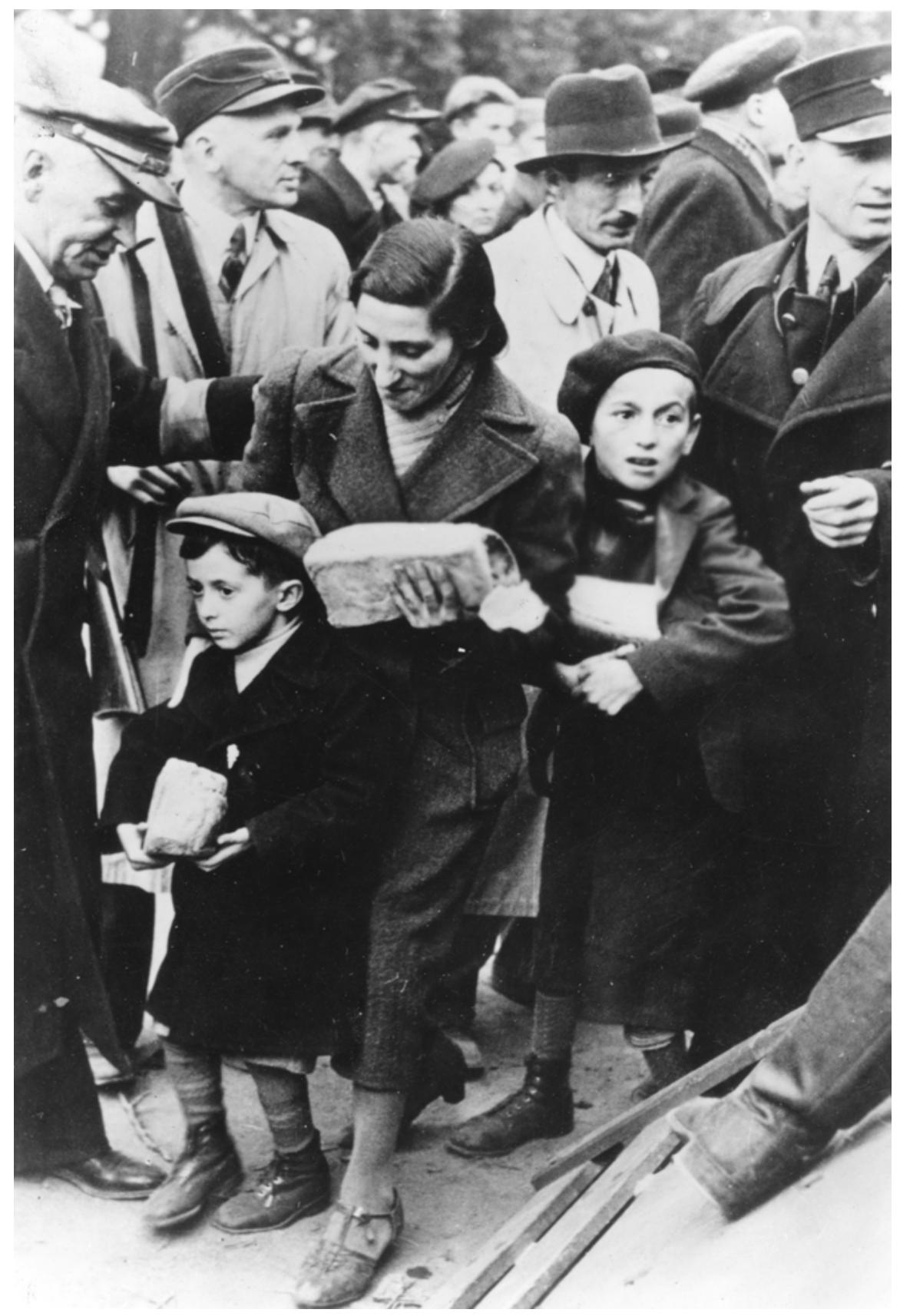

Fig. 4: Polish Jewish refugees. Vilna, Lithuania, 1939 (JDC Archives Photograph Collection, NY_06661) 


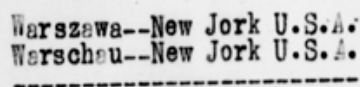

Prosbe o pomoc.

Gesuch um Hilfe.

Mr.10550. Bert Mochorowska, T-wa, Malicó $5 \mathrm{~m} .6$.

Simon Zimermen,506 Fort Nashington $/$ ven. New Jork.

Nr.10551. Rubin Mochorowski, $\mathbb{1}$. Wa, Naliców 5 m.6.

Louis Morrison, 79 Pifth Aven. New-Jork.

Nr.10552. Pubin Mochorowski, W-wa, Walic6w $5 \mathrm{~m} .6$.

Abe Worrison, 1864 West 4-th St. Broklyn N.J.

Nr.10553. Naten Nertman, N-we, Leszno $47 \mathrm{~m} \cdot 6$.

Prency Sperling,165 Suffolk str.New-Jork, City.

Nr.10554. Izak Nedel, "1-ws Targowe 53.

P.L.Pajgenbaun, 62 Irejer Str. Pochester New-Jork.

Nr.10555. Blźbieta Szrejder, N-we, Blektoralna 31 m.ll u p.oebroch. Semuel Kenn, 160 Brodway, New-Jork.

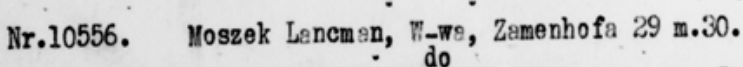

Sarah Blstein, 309 3.Houston str. New-Jork.

Nr.10557. Wolka Goldberg, W-Ws, Woliríske 4 m.16.

Sarch Blstein, 309 B.Houston str. New-Jork.

Nr.10558. Bstera Branfeld, Wowa, Zamenhof $a 21$ п. 81 .

Mejer Brennfeld for Machle Branfeld, 180 Orchard str.New-Jork.

Fig. 5: Calls for help from Polish Jews to US relatives sent via JDC, 14.5.1940 (JDC Archives, Records of the Warsaw Office of the American Joint Distribution Committee, 1939-1941, Folder \#164; http://search.archives.jdc.org/notebook_ext.asp?item=2629793) 
When the Nazis entered Poland, JDC-Warsaw, which was already working extensively in Poland, expanded its relief efforts in response to the emergency situation across the country and shifted its focus from reconstruction back to relief and financial assistance to communities. From September 1939 until the US entered the war in December 1941, JDC worked assiduously to save lives. By 1941, it supported 650 soup kitchens that served tens of thousands of meals daily, built temporary shelters for refugees, supported 200 hospitals and clinics, and provided childcare assistance - more than 2,000 institutions and agencies - in more than 408 locales. Although JDC struggled to provide aid in the face of dwindling funds, its efforts helped sustain many.

With the US entry into the war, the legal existence of JDC Warsaw came to an end, along with American allocations. Local JDC representatives continued their activities underground.

\section{Evian Conference and the Dominican Republic}

JDC Vice-Chairman Jonah B. Wise attended the Intergovernmental Conference for Refugees from Germany in Evian in 1938 as JDC's representative and tried to lobby for more countries to accept Jewish refugees. ${ }^{8}$ When the Dominican Republic agreed to accept Jewish refugees, JDC began negotiations that resulted in the establishment of the Dominican Republic Settlement Association (DORSA), an agricultural settlement of German and Austrian Jews in Sosua in the Dominican Republic, financed by JDC. ${ }^{9}$

\section{France}

With the influx of many refugees to France, JDC worked with local Jewish child care organizations such as OSE (Oeuvre de Secours aux Enfants), to establish children's homes for orphans and unaccompanied children who had been sent to France, and extended relief assistance to refugee families. Once France was

8 JDC Archives, Records of the New York Office of the American Jewish Joint Distribution Committee, 1933-1944, folder \#255, Jonah B. Wise, American Joint Distribution Committee Statement to the Intergovernmental Conference on Refugees, Evian, July 1938; http://search.archives.jdc. org/notebook_ext.asp?item=426835.

9 See Marion A. Kaplan: Dominican Haven: The Jewish Refugee Settlement in Sosua, 1940-1945, New York: Museum of Jewish Heritage - A Living Memorial to the Holocaust, 2008. For further information, see https://archives.jdc.org/our-collections/finding-aids/dorsa-collection/1939-1977. 
occupied by the Nazis, JDC, in close collaboration with the American Friends Service Committee, provided food and clothing for Jewish internees in transient and detention camps such as Gurs, St. Cyprien, and Camp des Milles in southern France.

\section{Spain and Portugal}

Later, when the Nazis entered southern France, many Jewish refugees crossed the Pyrenees to reach Spain, and JDC established an office in Barcelona and a wartime headquarters in Lisbon, the last outpost for those attempting to reach the Atlantic. The services extended by JDC in Spain included protection or intervention on the refugees' behalf, financial support, and assistance with their departure from Spain. JDC arranged for the evacuation of groups of children to the US, helped refugees communicate with friends and family, and provided medical care where possible.

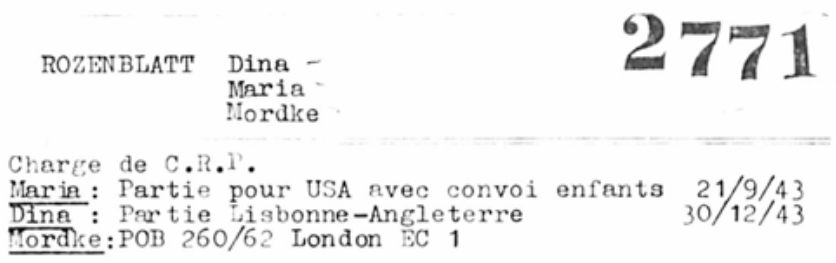

Fig. 6: Index Card for Rozenblatt Family, JDC Barcelona Office, case cards, 1943 (http://search. archives.jdc.org/notebook_ext.asp?item=133248)

More than 100,000 refugees passed through Portugal during the war years en route to overseas lands, and JDC provided care and maintenance and emigration assistance to most of them and operated children's homes there. JDC financed or shared in the financing of dozens of sailings from Lisbon and nearby ports using large ships such as the Nyassa for trans-Atlantic crossings and voyages to North Africa and Palestine. The Serpa Pinto carried between 700 to 800 passengers per sailing, and in the course of the Second World War, it bore more refugees across the Atlantic than any other single transport. Between 1941 and 1944, JDC fi- 
nanced or shared in the financing of over a dozen Serpa Pinto sailings, which brought Jewish refugees from Lisbon and Spain via Morocco and Tangier to Jamaica, Cuba, and the US. JDC archival records include lists of passengers whose fares were subsidized by JDC.

Jewish refugees were permitted to stay in Spain and Portugal only temporarily, and JDC sought to identify new emigration possibilities for the refugees. Overall, JDC needed to base its emigration plans on the refugees' countries of origin, depending on which nationals each country was ready to accept, either on a temporary or permanent basis. Polish Jews were taken to Gibraltar and England. Czechs were transferred to England. Many were taken to Tangier, an international city, and later from there to other countries, including Canada and the US. JDC's guarantee of care and maintenance costs often facilitated the refugees' acceptance.

\section{Cuba and Shanghai}

In Cuba, JDC established a refugee committee and worked closely with the local community to assist the many Jewish refugees who came to Cuba between 1938 and 1945. Likewise, JDC developed an extensive refugee assistance program in Shanghai, the only free port in the world ready to accept Jewish refugees without passports, to which approximately 20,000 Jewish refugees from Germany and Austria and later from Czechoslovakia and Poland escaped. The majority were destitute or nearly so, and JDC provided food and other services to over $16,000 .^{10}$

\section{Hungary}

JDC worked in Hungary to develop children's homes and welfare programs to assist needy Hungarian Jews impacted by the entry of the Nazis into Hungary in March of 1944. JDC, as a primary funder of the US War Refugee Board, was involved in sending Raoul Wallenberg to Hungary and the funding of his operations there. JDC's office in Istanbul sought to channel refugees from the Balkans to Palestine and to assist the many refugees arriving in Turkey, a neutral country.

10 For further background, see Zhava Litvac Glaser: "Laura Margolis and JDC Efforts in Cuba and Shanghai: Sustaining Refugees in a Time of Catastrophe”, in Avinoam Patt, Atina Grossmann, Linda G. Levi and Maud S. Mandel (eds.): The JDC at 100: A Century of Humanitarianism, Detroit: Wayne State University Press, 2019, 167-204. 
Thus, both prior to and during the Second World War, JDC was active in a large number of countries, both in Europe and beyond. The organization's experience from its work in the aftermath of the First World War, its longstanding relationships with Jewish communities across Europe, and its pre-existing partnerships with other nonsectarian agencies, enabled JDC to create early-on systems to collect and disseminate information on individuals that it assisted that would later facilitate family tracing and search efforts. JDC began preparing lists of refugees receiving JDC assistance even before the official outbreak of the Second World War and developed systems to share these lists with other JDC offices and other NGOs. JDC's know-how and the networks it had established made it well-positioned to lead efforts to help survivors and refugees after the war.

\section{Role of JDC in the Central Location Index}

Even before the end of the war, there was a need for a central clearinghouse in the US for inquiries from family members desperate to learn the whereabouts and fate of their relatives in Europe. With the outbreak of the war, communications were limited, and with the desperate attempts of European Jews to escape to other countries, it was increasingly difficult for family members to know where their relatives had gone. Those with family members in Europe frantically turned to a number of Jewish and non-sectarian organizations that were working in Europe to attempt to receive information. JDC played a central role in initiating a series of meetings during 1943 with other US agencies regarding the setting up of a US-based central location file for refugees. ${ }^{11}$

These organizations came together to create a Central Location Index (CLI), chartered on May 27, 1944, that was initiated by seven founding US organizations actively engaged in servicing US residents' inquiries for location of their relatives and friends: American Committee for Christian Refugees, American Friends Service Committee, American Jewish Joint Distribution Committee, Hebrew Immigrant Aid Society, International Migration Services, National Council of Jewish Women, National Refugee Service. Later they were joined by several additional organizations: Unitarian Service Committee, International Rescue and Relief Committee,

11 JDC Archives, Records of the New York Office of the American Jewish Joint Distribution Committee, 1933-1944, folder \#23, Moses A. Leavitt, Report of the Secretary to the Executive Committee Meeting of the Joint Distribution Committee, 27.10.1943, 4-5; http://search.archives.jdc. org/notebook_ext.asp?item=401367. 
Canadian Location Service, and American Federation of International Institutes. ${ }^{12}$ The CLI proved to be of great value in the difficult task of family reunification and eliminated duplication of inquiries and effort.

The CLI, established while the Second World War was still raging, beginning in May 1944, was a clearinghouse for all inquiries originating with the member agencies, and served as a channel to secure information from government-sponsored registration centers abroad. Utilizing a standardized CLI application form, each stateside organization would forward requests for information to CLI Headquarters in New York where the agency's request was filed in the CLI, and a central location file and index card were created for each refugee. Then an International Red Cross card was made out for each member of the dispersed family and sent to Geneva, ${ }^{13}$ and the CLI Headquarters would channel these requests to Europe. These procedures were established and already in operation by the autumn of 1944 as reported by Moses Leavitt to the Emergency Administration Committee of the Joint Distribution Committee on October 10, 1944.

In December 1945, the US War Refugee Board designated the CLI as the sole agency in the US to cooperate with UNRRA Central Tracing Bureaus in Germany and Austria. The CLI cleared its inquiries and information with the International Red Cross. Lists of Displaced Persons gathered by JDC and other overseas agencies in neutral and liberated countries and occupied areas were registered in the file and served as an additional source of information. These resources were the basis for checking inquiries by relatives in the US. The CLI sought to match names and help to locate the American relatives and friends sought.

JDC's primary work was overseas, and it did not service US relatives in the same way as US-based organizations with a mandate to service populations in the US. JDC, however, had an interest in creating this index in relation to its work overseas and the cooperation that its overseas staff could provide. JDC was the primary funder of the CLI, and the CLI president was Moses Leavitt, JDC Secretary from 1940 to 1946 and Executive Vice-Chairman from 1947 to 1965. Etta Deutsch served as CLI executive director from its founding in 1944 until November 1948, and Carolin Flexner served thereafter for the last six months until the organization closed down. They led a staff of 75 trained searchers.

12 "Agency to Find Relatives in Liberated Europe Established in New York”, August 9, 1944, Jewish Telegraphic Agency, JTA Archives.

13 JDC Archives, Records of the New York Office of the American Jewish Joint Distribution Committee, 1933-1944, folder \# 63, Minutes of the Emergency Administration Committee of the Joint Distribution Committee, 10.10.1944, 21-22. 


\begin{tabular}{|c|c|c|c|c|c|c|}
\hline $\begin{array}{l}\text { APPLICATION FOR } \\
\text { LOCATION SERVICE }\end{array}$ & \multicolumn{2}{|c|}{$\begin{array}{l}\text { Please print or urite clearly. } \\
\text { Please anstcer all questions } \\
\text { "I you do not have the information, } \\
\text { "enter "unknoun." }\end{array}$} & \multicolumn{4}{|c|}{$\begin{array}{l}\text { NATIONAL COUNCIL OF JEWISH WOMEN } \\
1819 \text { Broadway } \\
\text { New York 23, N. Y. }\end{array}$} \\
\hline \multicolumn{7}{|l|}{ A. PERSON(S) SOUGHT } \\
\hline Fanily name as known abros & First Name & Sex & $\frac{\mathrm{Mn}^{\circ}}{\mathrm{S}}$ & $\begin{array}{l}\text { Relationshis } \\
\text { to } \mathrm{No}_{0} 1\end{array}$ & $\begin{array}{l}\text { Date of } \\
\text { Birth } \\
\end{array}$ & Place of Birth \\
\hline 1. POCIBIGIXI, & LeIb & M & $x$ & $\mathrm{x}$ & $\begin{array}{l}\text { about } \\
1885\end{array}$ & Low1ez, Folend \\
\hline
\end{tabular}

B. OTHER MEMBERS OF THE FAMILY OR HOUSEHOLD ABROAD in you are ales secking one of more persons lised below check ( $V$ )

\begin{tabular}{|c|c|c|c|c|c|c|}
\hline (2. POC TENGIKI, & Szymon & $\underline{I I}$ & $s$ & son & 1917 & Clouno, Poland \\
\hline (2. FOCIBNGIEL, & Tzyvia & $\underline{r}$ & $s$ & đaughter & 1915 & $n$ \\
\hline (4. POCIENGIEL, & Awrum & $M$ & $s$ & son & 1925 & $n$ \\
\hline (x 5. POCIRNGIRL, & Czarna & I & s & daughter & 1930 & $n$ \\
\hline \multicolumn{7}{|l|}{$\square 6}$. \\
\hline ㄱ. & & & & & & \\
\hline
\end{tabular}

C. ADDITIONAL IDENTIFYING DATA ON PERSONS LISTED ABOVE

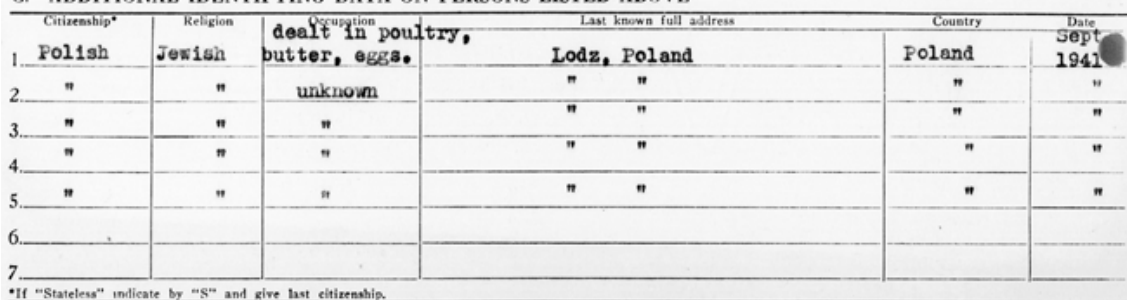

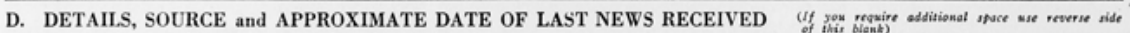
(Isticate by number above the person or pernoess about whom you have the news)

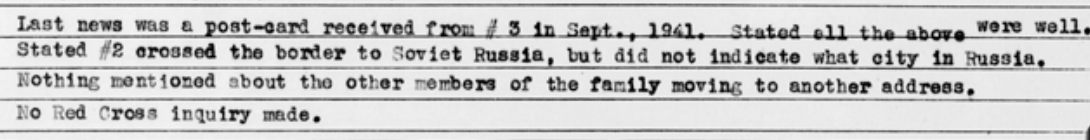

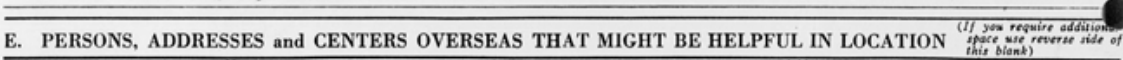

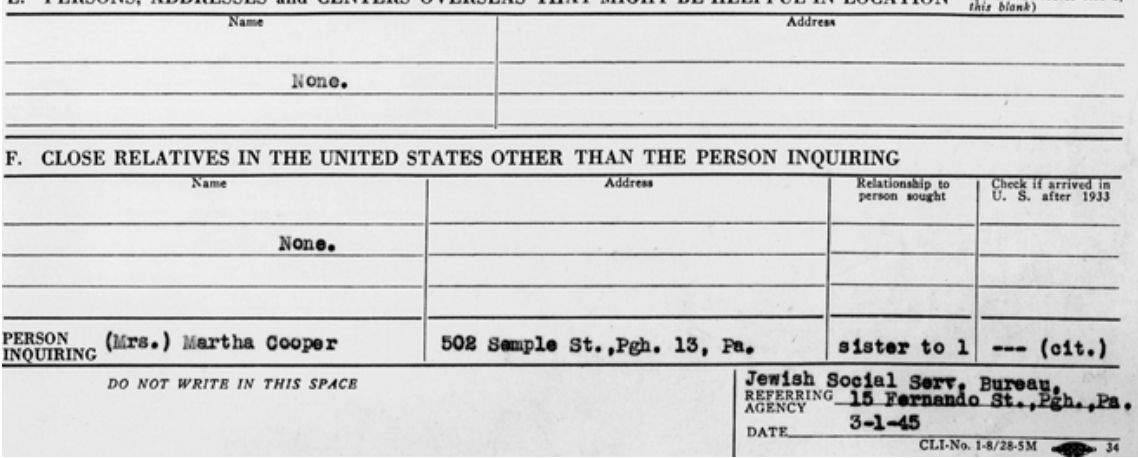

Fig. 7: Application for Location Service, 1.3.1945 (JDC Archives, Records of the Warsaw Office of the American Joint Distribution Committee, 1945-1949, Folder \#873; http://search.archives.jdc. org/notebook_ext.asp?item=2274927) 
The CLI received cables from Europe in February 1945 with names of 1,200 people rescued from Theresienstadt who had arrived in Switzerland. CLI staff were able to match many of these individuals with inquiries in the CLI records, demonstrating the benefits of a central index. This unexpected development led to great excitement. Thus began an active process whereby lists of liberated internees from the various concentration camps were sent to the CLI which immediately sought to make matches with their inquiry records. ${ }^{14}$

Already in October 1944, Moses Leavitt reported to the JDC Emergency Administration Committee about the CLI work in the US and his concerns about the inadequacy of tracing efforts of the International Red Cross system overseas. He stressed the need for a local service in every country. Since most location inquiries would be Jewish requests, Leavitt proposed that JDC had a major contribution to make in this regard. He indicated that UNRRA agreed about the need for national tracing offices but was not itself interested in establishing local national tracing offices. UNRRA efforts would only be temporary as UNRRA would be closing down its operations. Joseph Schwartz, JDC Director of Overseas Operations, noted that refugees want first and foremost assistance with finding their family. The committee authorized Dr. Schwartz to study how JDC might establish local tracing and family search offices in Europe with local staff which would work in consultation with local organizations such as Red Cross chapters or municipalities. ${ }^{15}$

From 1944 to 1949, the Central Location Index processed appeals for aid in locating 750,000 people. They were able to find 50,000 persons in postwar Europe for relatives inquiring from all over the world. Of these, 40,000 persons were alive, and information on their whereabouts was shared with their relatives. Deaths or deportations of 10,000 individuals were confirmed. To do this, the CLI maintained 1.2 million file cards and files. Lost and orphaned children were a particularly difficult problem. The total cost of this operation was $\$ 450,000$. $^{16}$

14 JDC Archives, Records of the Geneva Office of the American Jewish Joint Distribution Committee, 1945-1954, folder \#ORG.320, Etta Deutsch, History of the Central Location Index, Inc., May, 1949, 5; http://search.archives.jdc.org/notebook_ext.asp?item=2143458.

15 JDC Archives, Records of the New York Office of the American Jewish Joint Distribution Committee, 1933-1944, folder \# 63, Minutes of the Emergency Administration Committee of the Joint Distribution Committee, 10.10.1944, 21-25.

16 JDC Archives, Records of the Geneva Office of the American Jewish Joint Distribution Committee, 1945-1954, folder \#ORG.320, Etta Deutsch, History of the Central Location Index, Inc., May, 1949; http://search.archives.jdc.org/notebook_ext.asp?item=2143458. See also JDC Archives, Records of the New York Office of the American Jewish Joint Distribution Committee, 1945 - 1954, folder \#1541, Press release: “Central Location Index Ends Missing Persons' Hunt”, 12.5.1949; http://search.archives.jdc.org/notebook_ext.asp?item=607207. 
As JDC local offices in countries around the world received inquiries, these local offices would seek information from local contacts and institutions on the subject of the inquiry and respond to the inquiring office with copies to other offices around the world. In this way, many times, an individual might be found in Poland, but a sibling might be found in Belgium. With this broad communication, JDC was successful in reconnecting many relatives. JDC staff members themselves were often personally affected. For example, A. Malamoud of JDC Warsaw wrote to JDC Brussels on February 29, 1948, expressing thanks for information on the whereabouts of his cousin, Karola Eisenberg, who was now in Stockholm. ${ }^{17}$

Often, relatives in the US did not know all the names of family members in Europe. So, for example, the ITS final report quotes a letter from JDC Warsaw: "We were fortunate enough to locate the brother of the sought Morris. He is Chaim M. aged 27. born at Jasniowska, distr. Bialystok. His parents: Abram and Lejka, maiden name K. Mr. M. stated that he is the only survivor of his whole family and that he is a brother of Morris. His present address is Warsaw, Roznanska 38/14.”18

In the years immediately following the Second World War, the various offices of the organization worked tirelessly to trace family members of survivors, collaborating closely with the CLI. Many lists of survivors or emigrants assisted by the Joint or refugees seeking relatives were produced and disseminated, some of which included names and addresses of relatives in the US. After the CLI was disbanded, the documentation was stored by JDC in New York; in 1957, this documentation was transferred to Yad Vashem in Jerusalem. Copies of the CLI registration cards were shared with the International Tracing Service when it was established.

17 JDC Archives, Records of the Warsaw Office of the American Joint Distribution Committee, 1945-1949, folder \#1162, letter from A. Malamoud of JDC Warsaw to JDC Brussels, 19.2.1948; http://search.archives.jdc.org/notebook_ext.asp?item=2312390.

18 JDC Archives, Records of the Geneva Office of the American Jewish Joint Distribution Committee, 1945-1954, folder \#ORG.320, Etta Deutsch, History of the Central Location Index, Inc., May, 1949, 7; http://search.archives.jdc.org/notebook_ext.asp?item=2143458. 


\section{JDC during the Immediate Post War Period}

\section{Displaced Persons Camps in Germany, Austria and Italy}

When Saly Mayer, JDC representative in Switzerland, made his first visit from May 26 to 28, 1945, to the Displaced Persons camps in Germany, he cabled JDC New York outlining his observations and conclusions. The following two points were among the priority action points: "THREE: All most anxious to find out if and where missing members of their family are living FOUR: They are most anxious that their relatives abroad are informed of their being still alive and of present address." ${ }^{19}$ Several days after receiving Mayer's June 6 and 8 cables, Harold Trobe, JDC Representative in Vienna and Prague, in a handwritten note to Joseph Schwartz and Moses Leavitt, wrote:

Lists with incomplete data seem to circulate all over Europe without much rhyme or reason. Can the Int. Red Cross handle the whole job or must there be a Jewish location index as well? [...] I know how difficult the task is. It will take all the ingenuity of the Int Bus Machine people plus many others whose hearts are in the task. ${ }^{20}$

By late 1945, tens of thousands of European Jews, aided by underground networks of guides, had flooded into the US and British occupation zones in Germany and Austria. They crowded into Displaced Persons camps that were hastily set up by the Allies to house the hundreds of thousands of people displaced by the war. The United Nations Relief and Rehabilitation Administration (UNRRA) was responsible for the basic needs of refugees. It became immediately apparent that the Jewish inhabitants had very different needs, and the devastation to their communities was more complete. They also needed protections from their fellow inhabitants who were often hostile to them.

Joseph Schwartz accompanied Earl Harrison, President Truman's Special Envoy, on his official tour of the camps. As a result of this visit and the report submitted, separate camps were established for Jewish DPs. JDC received permission from UNRRA and the US Army to work within the DP camps supplementing

19 JDC Archives, Records of the New York Office of the American Jewish Joint Distribution Committee, 1945-1954, folder \#323, Cable from Saly Mayer in St. Gallen to American Joint Distribution Committee New York, 8.6.1945; http://search.archives.jdc.org/notebook_ext.asp?item= 674481.

20 JDC Archives, Records of the New York Office of the American Jewish Joint Distribution Committee, 1945-1954, folder \#1051, letter from Harold Trobe to Joseph Schwartz and Moses Leavitt, 14.6.1945; http://search.archives.jdc.org/notebook_ext.asp?item=624304. 
the meager aid provided by UNRRA. In addition to providing food, clothing and healthcare, JDC opened schools and developed cultural and religious activities within the Displaced Persons camps. The JDC Emigration Service in Munich and Vienna assisted Jewish refugees with information, applications, visas, papers, and help to fund their emigration. A file was created for each family, and a card index was maintained of all individuals. These cards have been indexed in the JDC Archives Names Index.

In Italy, as well, JDC provided assistance to the many refugees in Rome and in smaller camps including ten children's homes in Selvino, Campolecciano and elsewhere, a TB rehabilitation center in Grottaferrata, and vocational training programs at Ostia, Fano, and elsewhere. The JDC Rome Emigration Service assisted Jewish families with emigration.

\section{Poland}

In Poland, JDC embarked upon a massive assistance program for shattered survivors in the immediate postwar period. It shipped vital supplies to the needy, promoted economic activity, supported a network of schools, homes, hospitals, and cultural institutions, and assisted tens of thousands to emigrate to Israel and other countries, including many children who were retrieved from the families and churches who had hidden them during the war. Many of these children no longer had parents, and the search for their relatives was a complicated endeavor.

JDC Warsaw worked extensively to prepare applications to the Conseil Interoeuvre d'Aide aux Immigrants et Transitaires Juifs in Paris for the emigration of Jewish children to France. Many of these children ultimately continued to Israel. The JDC Warsaw Emigration Service maintained family files and a card index for each individual. What remains of this card index has been digitized and is searchable in the JDC Archives database.

\section{Children in France}

Following the war, in 1945, there were over 15,000 Jewish children in France, 11,000 of them needy and receiving assistance from JDC. Over 9,000 children were in Jewish childcare institutions operated by OSE and other local organizations. All of these institutions were supported primarily by JDC. JDC was also providing relief support to 2,000 children via their families and Jewish children placed in foster homes by OSE and other organizations. Among these children 
were many orphans including 535 Buchenwald child survivors admitted temporarily en route to Palestine, ${ }^{21}$ and children of Jewish refugees streaming in from Soviet-occupied countries including Poland and other East European countries.

\section{Shanghai}

Between the resumption of emigration in 1946 and 1953, JDC helped 16,000 Jews, mostly living in Shanghai, leave China for other lands. Approximately 6,700 were admitted to the US. The remainder went to Israel, Europe, Australia, Latin America, and Canada.

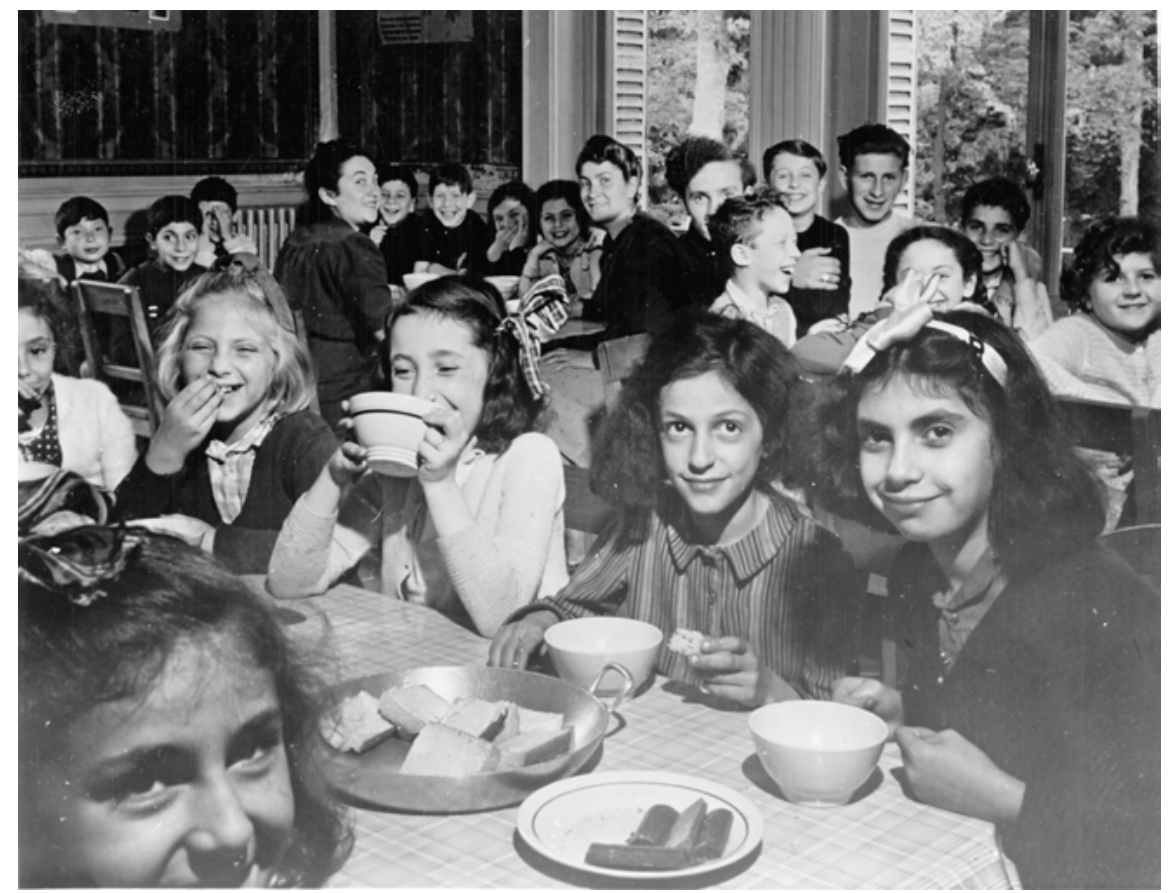

Fig. 8: Dining hall of an OSE children's home in France, c.1947 (JDC Archives Photograph Collection, NY_07983)

21 JDC Archives, Records of the Istanbul Office of the American Jewish Joint Distribution Committee, 1937-1949, folder \#IS.181, Orphan Children from Buchenwald Now in Paris: Enfants Venus d'Allemagne-Convoi du 8 Juin 1945 à Écouis, 8.6.1945; http://search.archives.jdc.org/ notebook_ext.asp?item $=875790$. 
When the communist government took over in China, it became clear that JDC would need to leave. It closed its offices in 1949, and it became imperative for the refugees to leave. JDC assisted the refugees to find temporary and permanent immigration solutions and helped to fund the travel for the needy. For some, there was no recourse other than leaving China and returning to Austria and Germany via the US, which would not permit entry to those without US visas. In some cases, refugees had to travel from Shanghai to San Francisco and from there across the country in sealed trains to New York to board ships and planes back to Austria and Germany.

\section{JDC Tracing Services in the Post-War Period}

Initially, there was no mail service in the military zones of Germany and elsewhere. This made communication often impossible. JDC began to develop local tracing bureaus in localities where it was working. The methodology was to create lists of survivors and card indexes with their names. JDC assisted Jews in searching for relatives, served as a liaison with the Central Location Index in New York and other JDC offices, placed newspaper ads, and pursued inquiries with other organizations.

Beginning in June 1945, JDC established the JDC Tracing Service in the US Zone of Germany. The first step was to encourage the survivors themselves to create lists of survivors. The Central Committee of Liberated Jews, established in June 1945, prepared lists of Jewish survivors in Germany. JDC supported this effort financially. JDC created a card index and assisted Jewish survivors in the search for their relatives. By September 1946, 14,313 individuals had requested assistance with the tracing of relatives from the JDC Tracing Service in the US Zone of Germany. ${ }^{22}$ If addresses of US families were not known, tracing staff utilized telephone directories from large US cities or turned to the CLI and other JDC offices. The JDC Tracing Services placed ads in newspapers and made inquiries with other organizations. By January 1947, the JDC Tracing Service in the US

22 JDC Archives, Records of the Geneva Office of the American Jewish Joint Distribution Committee, 1945-1954, folder \#GER.63, Memorandum from Leo W. Schwarz to Dr. Joseph Schwartz, Subject: Summary Analysis of AJDC Program in the U.S. Zone of Occupation, Germany, 13.1.1947, 19-20; http://search.archives.jdc.org/notebook_ext.asp?item=2057018. 
Zone of Germany had assigned 14 staff to tracing work, and during 1947, it had 29,037 inquirers and 15,054 positive results. ${ }^{23}$

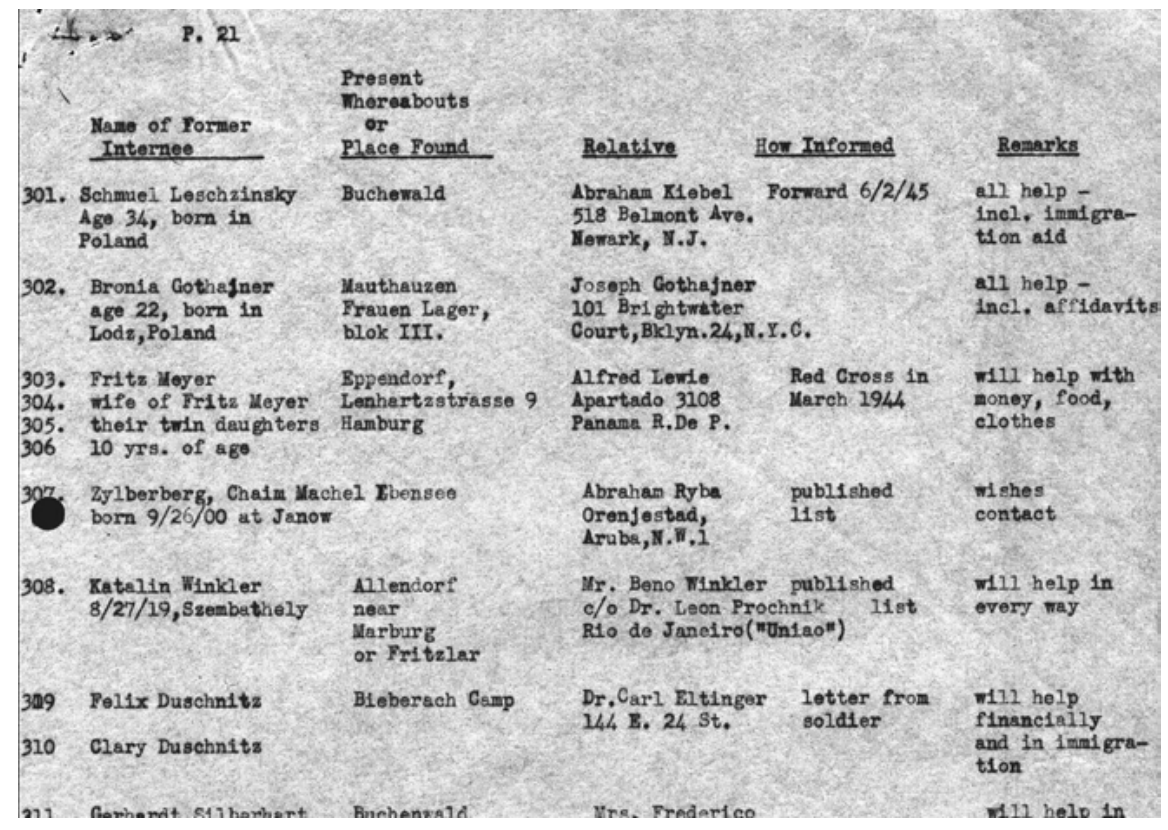

Fig. 9: Portion of a page from a list of survivors, 7. 8.1945 (JDC Archives, Records of the New York Office of the American Jewish Joint Distribution Committee, 1945-1954, folder \#1051, Survivor Lists: General, 1944-1945; http://search.archives.jdc.org/notebook_ext.asp?item=624286)

In Berlin, the JDC Berlin Search Bureau was established based on information gathered from the Gestapo Deportation Index, which included the names of 126,000 Jews deported from Berlin and a card index of 140,000 Dutch Jews who were deported. This index was shared with the Dutch Jewish Community and with the CLI. ${ }^{24}$

23 JDC Archives, Records of the Geneva Office of the American Jewish Joint Distribution Committee, 1945-1954, folder \#GER.81, Report of Activities in the United States Zone of Occupation for the Year 1947, 25; http://search.archives.jdc.org/notebook_ext.asp?item=2057329.

24 JDC Archives, Records of the Geneva Office of the American Jewish Joint Distribution Committee, 1945-1954, folder \#GER.783, Larry Lubetsky, A Report on the Activities of the AJDC Berlin Tracing Office, January 1 thru March 31 ${ }^{\text {st }}$, 1947, April, 1947, 1-2; http://search.archives.jdc.org/ notebook_ext.asp?item=2101170. 
In the British Zone, JDC established the Belsen Joint Tracing (Search) Department. Resources included the lists of survivors prepared by the camp committee and UNRRA registers. A card index was prepared using lists of people in the British Zone, including those from all communities and Gemeindes, and three DP camps. $^{25}$

\section{JDC Opens Local Tracing Bureaus in Europe and Elsewhere}

Elsewhere in Europe, most Jewish refugees returned first to their hometowns to seek family and news of those who had survived. Most were devastated to realize the enormity of the loss of family and friends, and to the Jewish people as a whole. JDC offices in Europe opened local tracing bureaus to assist survivors of all ages, some of whom had been separated from spouses and children during the war. Following the disappointment of not finding loved ones, they often proceeded on the journey to the Displaced Persons camps in Germany, Austria, and Italy.

The search for family not only emanated from overseas family members in the US and elsewhere. Survivors themselves were seeking family members and requested assistance in tracing their overseas relatives. With so many family members having been lost in the war, tracing overseas relatives was seen as their salvation for a better future. Another area of activity for JDC local tracing bureaus was putting surviving relatives in touch with each other. Often, the parties did not know of each other's survival.

In the post-war period, all JDC offices in Europe, and in other countries where the organization was involved with large refugee programs, established local tracing bureaus to assist survivors to reconnect with their family and friends and to connect with overseas relatives. The tracing bureaus communicated with local groups, UNRRA tracing bureaus, and the Red Cross to seek information and corresponded with other JDC offices around the world and with the CLI to seek information in the search for relatives.

The JDC Overseas Headquarters moved back to Paris immediately after the war and established a vital, bustling location and tracing service. For a period in July 1947, there was an experiment to make JDC Paris the headquarters for all JDC location and tracing services. The Paris office transferred to the Interna-

25 JDC Archives, Records of the New York Office of the American Jewish Joint Distribution Committee, 1945 - 1954, folder \#301.1, undated memorandum from Belsen Joint Tracing Department; http://search.archives.jdc.org/notebook_ext.asp?item=671932. 


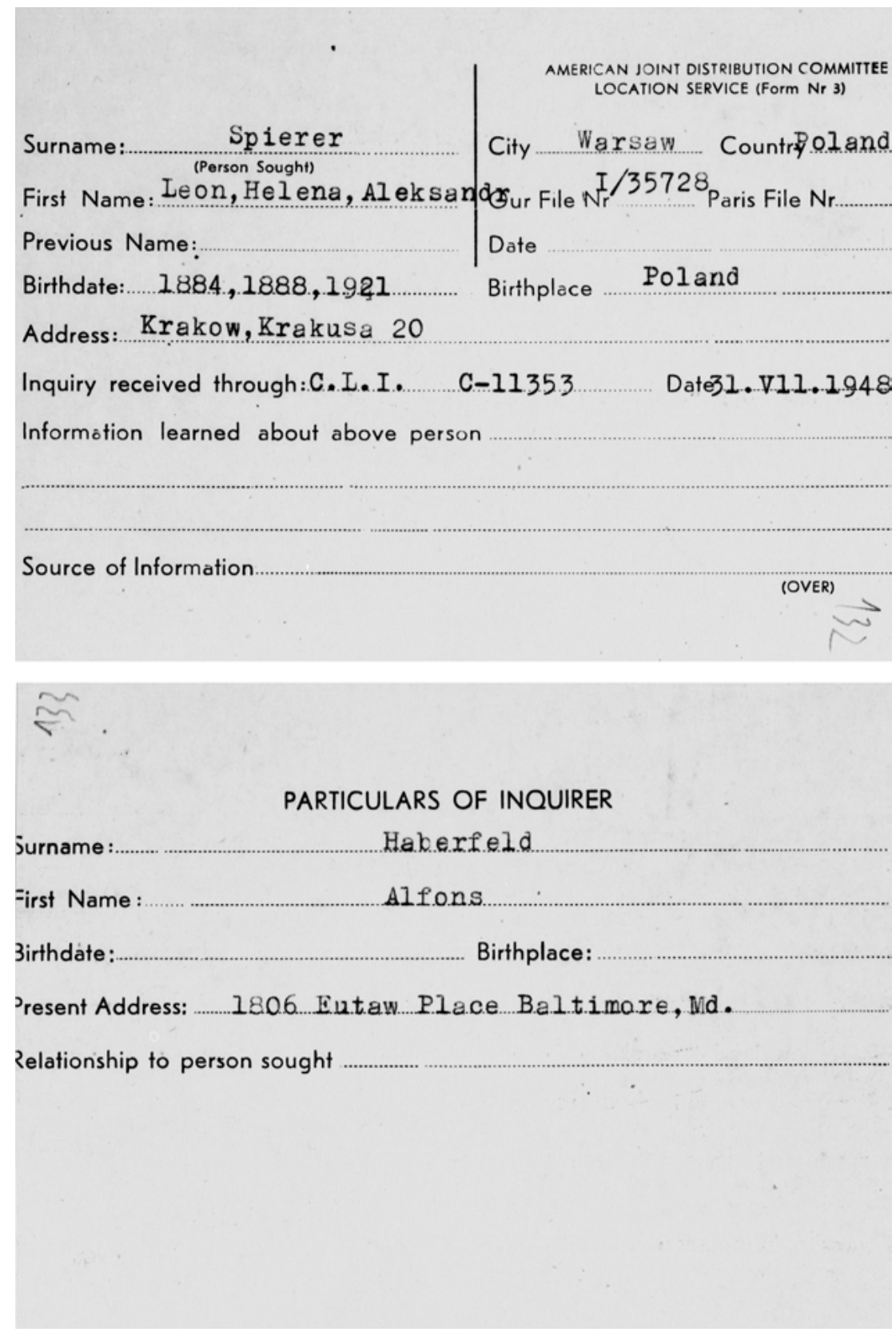

Fig. 10: Front and back of a JDC Location Service index card for inquiry received from the Central Location Index, 31.7.1948 (JDC Archives, Records of the Warsaw Office of the American Joint Distribution Committee, 1945-1949, folder \#1023; http://search.archives.jdc.org/notebook_ ext.asp?item=2292715) 


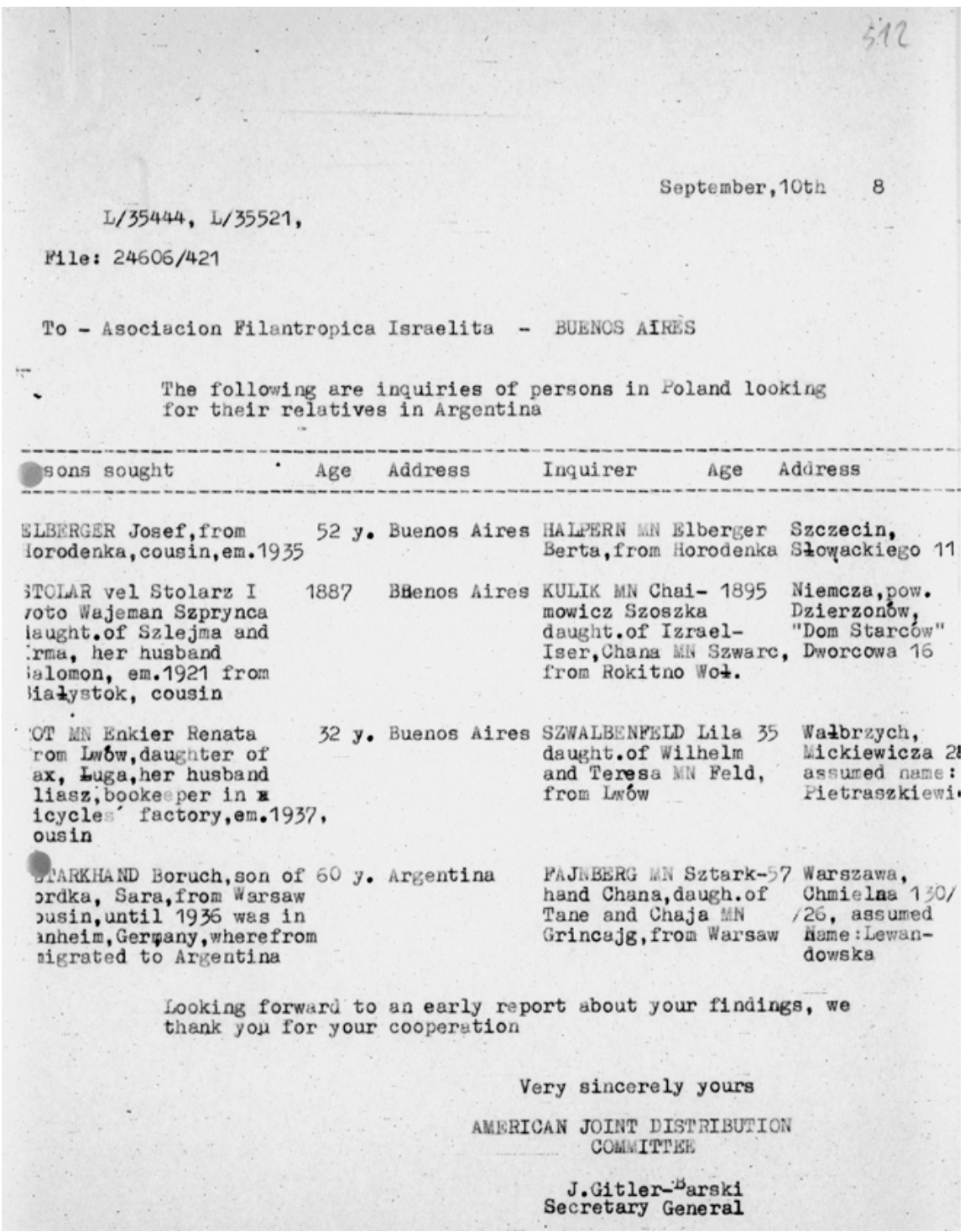

Fig. 11: Letter from J. Gitler-Barski, JDC Warsaw, to Asociacion Filantropica Israelita, Buenos Aires, regarding inquiries of Polish Jews seeking relatives in Argentina, 10.9.1948 (JDC Archives, Records of the Warsaw Office of the American Joint Distribution Committee, 1945-1949, folder \#618; http://search.archives.jdc.org/notebook_ext.asp?item=2231260)

tional Tracing Service over 30,000 emigration service cards from its emigration service. 
JDC offices maintained lists and card indexes of survivors and helped in the painstaking search for friends and relatives of the survivors. JDC Warsaw records from 1945 to 1949 reveal relentless activity to assist survivors to find their relatives. A file entitled "Correspondence: Thank you letters for help in locating missing persons" includes 70 documents, most of them in Polish and Yiddish. A September 1946 letter from the Jewish Search Centre in London to JDC Warsaw notes: "not only we but the enquirers as well are most grateful to you for your excellent search-work and the valuable assistance you gave us. May G-d bless your welfare work in 5707, and we wish you leshonah tauvoh." A March 13, 1947, letter from the Canadian Jewish Congress location service thanks JDC Warsaw for finding Mendel Wiseman-Wajsman, the relative of Mrs. Mandelbaum in Windsor, Ontario. A March 12, 1947, letter from a house painter in New York expresses thanks for locating the sender's nephew, Izzi Kempler, in Poland, and notes that he has already heard from Kempler. ${ }^{26}$

JDC Warsaw established its location department in October 1945, and JDC Rome's Location Service Bureau was established in January 1946. In Warsaw, a card index was prepared with 30,000 names of persons sought. Tracing activities were conducted in cooperation with other JDC offices. Ads were placed in the Polish/Yiddish press. ${ }^{27}$ Between October 1945 and September 1946, the JDC Warsaw office received 22,148 letters, wrote 16,963 letters, was successful in locating 3,450 cases in Poland, and contacted 1,095 persons abroad. During this period, it placed 30,882 search ads in newspapers. ${ }^{28}$

The Warsaw office made extraordinary efforts to search for children and financed the redemption of Jewish children from Polish families, established and supported orphanages, provided health care, granted scholarships, and prepared children for emigration. ${ }^{29}$

26 JDC Archives, Records of the Warsaw Office of the American Joint Distribution Committee, 1945-1949, folder \# 1162, Correspondance: Thank you letters for help in locating missing persons.

27 JDC Archives, Records of the Warsaw Office of the American Joint Distribution Committee, 1945-1949, folder \#642, Newspaper clippings from "Dos Naye Lebn" (The New Life; Lodz) and "Nowym Życiu" (New Life; Wroclaw) with the lists of names of persons sought. See, for example, page 30 of the document in this folder.

28 JDC Archives, Records of the New York Office of the American Jewish Joint Distribution Committee, 1945-1954, folder \#734, Report January - September 1946, AJDC Poland, 7.10.1946, $13-14$.

29 See finding aid for JDC Archives, Records of the Warsaw Office of the American Joint Distribution Committee, 1945-1949; https://archives.jdc.org/our-collections/finding-aids/warsaw/ 1945-1949/. 


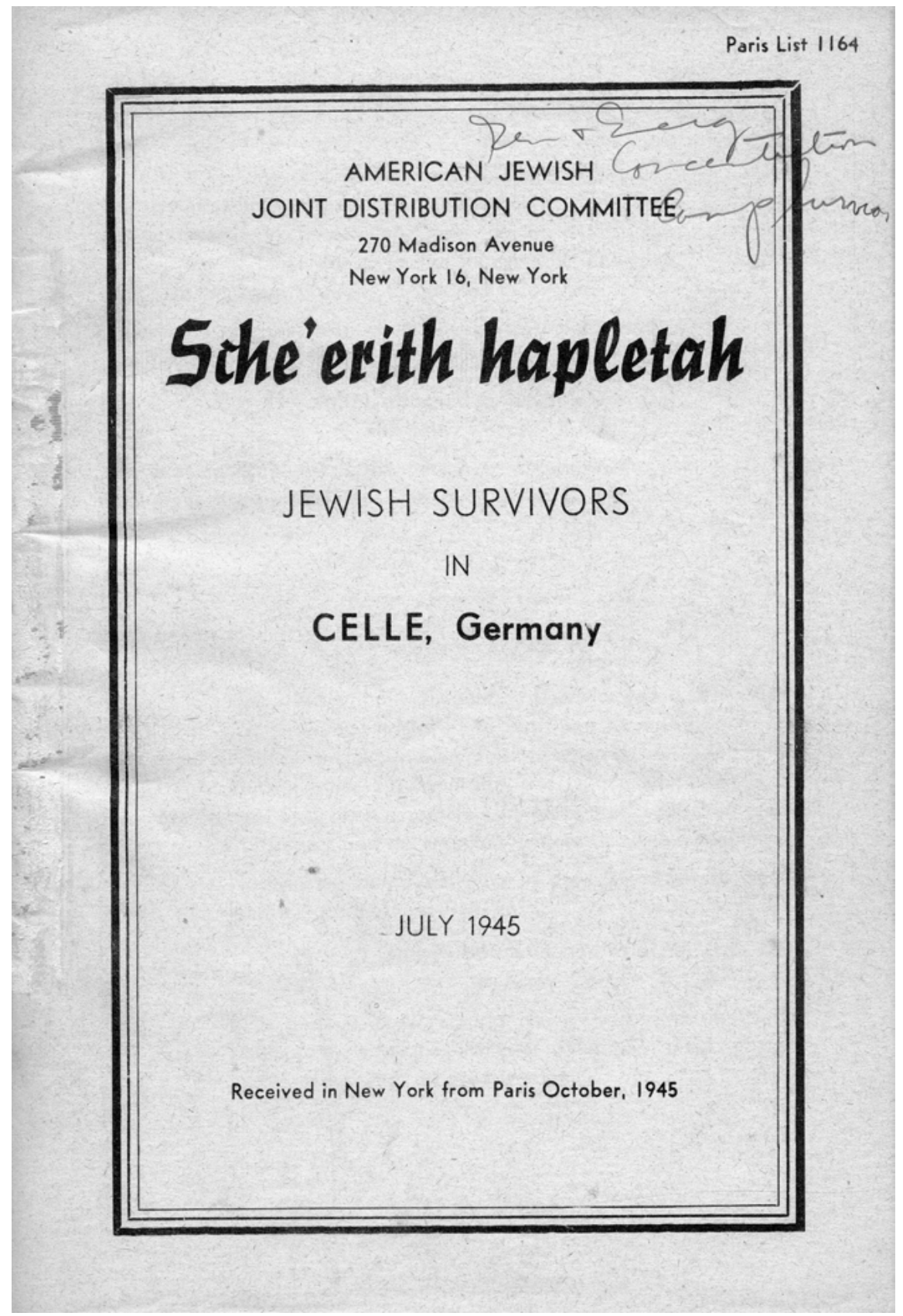

Fig. 12: Sche'erith Hapletah (The Surviving Remnant): Jewish Survivors in Celle, Germany, New York: American Jewish Joint Distribution Committee, July 1945 (JDC Archives, Records of the New York Office of the American Jewish Joint Distribution Committee, 1945-1954, folder \#1057; http://search.archives.jdc.org/notebook_ext.asp?item=624387) 


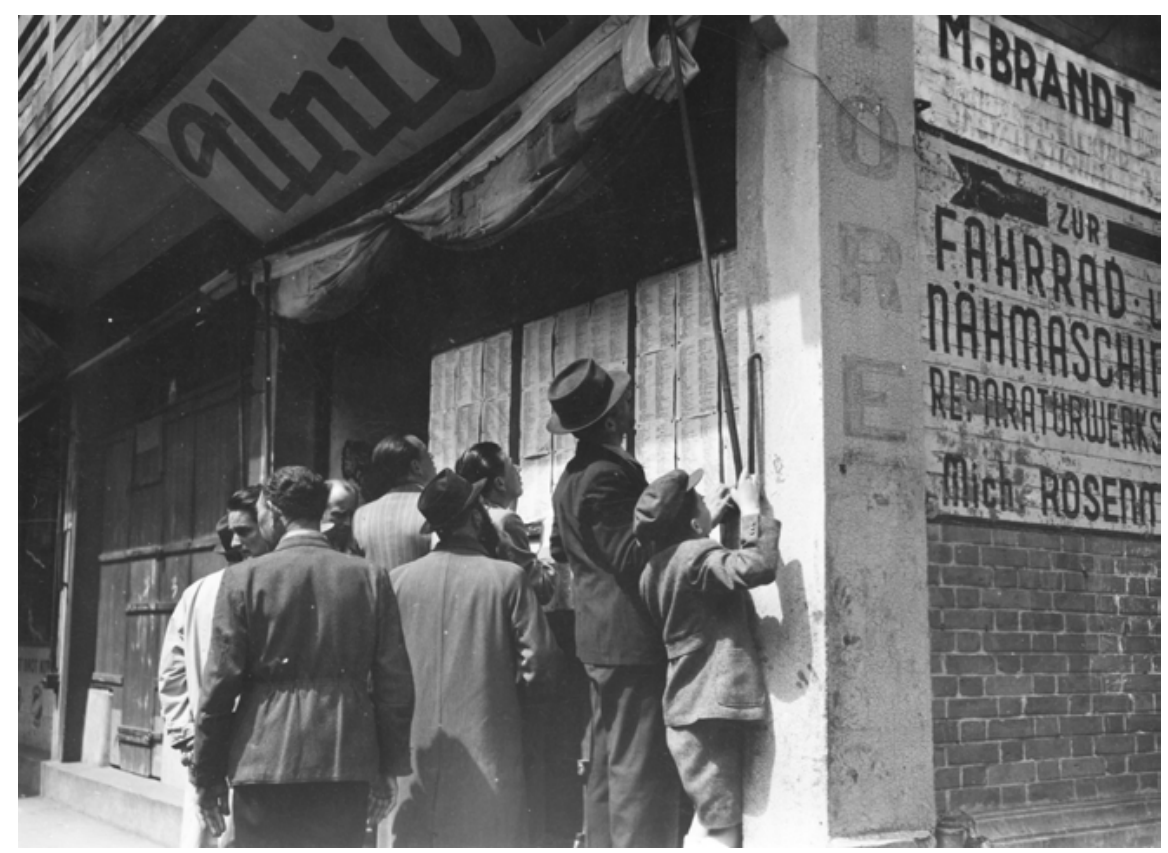

Fig. 13: Jewish refugees in Shanghai look for names of relatives and friends who may have survived the war. Shanghai, China, 1946 (Photograph: Arthur Rothstein. JDC Archives Photograph Collection, NY_17434)

JDC's Central Location Service in Rome maintained offices in Rome and Milan and was the sole organization in Italy dealing with large-scale tracing of Jews. It created a card index with 82,000 cards of Jews who fled to Italy, passed through Italy, or were deported from another country. In addition, 866 search lists were created. Over 13,000 cases were handled in 20 months. $^{30}$

In places where refugees congregated, such as the Lutetia Hotel in Paris or in Shanghai, for example, bulletin boards posted lists of united families and missing persons. Booklets and books with lists of survivors from certain localities, e. g. Jewish Survivors in Celle, Germany, published in July 1945, or a two-volume book listing survivors in Slovakia published by JDC in New York based on information received from overseas offices and shared with the CLI in New York and with the JDC office in Jerusalem. In Palestine, names of Holocaust survivors on

30 JDC Archives, Records of the New York Office of the American Jewish Joint Distribution Committee, 1945 - 1954, folder \#627, Louis D. Horwitz, Location Service Bureau Quarterly Report July - September 1947, Rome; http://search.archives.jdc.org/notebook_ext.asp?item=701980. 
these lists were read daily on Kol Israel radio, to inform new immigrants who eagerly awaited word of living family members. ${ }^{31}$

\section{Complexity of Location and Tracing}

Despite good will and good intentions, lists of survivors could often be problematic. These lists indicated where a person was at a particular point in time. During a period of havoc and emergency, many people were on the move. Thus lists of survivors don't reveal information on where these survivors went, whether they are still alive, etc. In addition, the lists often do not contain sufficient identifying data. There might be a number of people with the same name, and how could a family member ascertain that the person on the list was his/her relative? There may be a list of names but where could these individuals now be found? Many lists contained out-of-date addresses. Even when a family member was found on a list, painstaking work still needed to be done to try to ascertain whether the person was still alive and where they might be. Sometimes, relatives may have had contact and were known to be alive, but their whereabouts were unknown. This was prevalent particularly among those who moved from the East to the West.

Tracing relatives of children who were alone, often without a request from an inquirer, was particularly difficult. Often overseas relatives may not have known of the existence of the child or may not have known the child's name. Children did not have knowledge of their overseas relatives.

\section{Background on the International Tracing Service}

In February 1946, UNRRA accepted responsibility for tracing persons eligible for UNRRA care, including those receiving UNRRA care in Germany, eligible people not yet receiving care, and those technically eligible but no longer living. The Central Tracing Bureau (CTB) headquarters was established in 1946 at Arolsen, Germany, at the UNRRA headquarters. ${ }^{32}$

The objectives [...] [of the CTB] were to search for missing military and civilian persons... and establish the fate of those who could not be found; to locate, collect, and preserve

31 JDC Archives, Records of the New York Office of the American Jewish Joint Distribution Committee, 1945-1954, folder \#1051, Reshimot Nitzolim (Lists of Survivors).

32 See the article by Christian Höschler and Isabel Panek in this volume. 
all available records regarding refugees and displaced persons in Germany; and to serve as a link to bring interested persons into communication with each other. ${ }^{33}$

Zonal tracing bureaus were to be operated under the military commanders in each zone. In addition, individual UN member countries were encouraged to open national tracing bureaus that would receive initial inquiries concerning their own nationals and initiate tracing and search activities in their respective zones. The CTB was to operate as a central clearing house between zonal and national bureaus.

With plans to cease UNRRA operations in Arolsen on June 30, 1947 and to transfer UNRRA headquarters to Paris, the future of the Central Tracing Bureau was reviewed. Beginning in February 1947, individual and child tracing services were decentralized to the zonal tracing bureaus. The UNRRA CTB in Arolsen retained the central records office and mass tracing through newspapers and radio.

On July 1, 1947, with the closing down of UNRRA operations in Arolsen, the Provisionary Committee of the International Refugee Organization took over the UNRRA Central Tracing Bureau with "three main functions: 1) collective search, 2) formation of a library and catalogue, and 3) tracing on an international scale." ${ }^{34}$ In addition, the CTB was to coordinate work of the national tracing bureaus. To carry this out, the help of the International Committee of the Red Cross (ICRC) was enlisted, and the ICRC senior tracing expert, Mr. Maurice Thudichum, was seconded to help convert the Central Tracing Bureau into an International Tracing Service. The mandate of the ITS was "to include [...] the tracing of all non-German nationals, and of such German nationals as would be eligible under the constitution of IRO, who have disappeared by reason of the War." 35

The International Tracing Service began operations on January 1, 1948. All governments and voluntary organizations involved in tracing work were invited to relate their activities to the work of the ITS and make arrangements to exchange information. The zonal tracing bureaus were to be subsumed within the ITS.

33 JDC Archives, Records of the Geneva Office of the American Jewish Joint Distribution Committee, 1945-1954, file \#ORG.430, Report submitted by the Director-General of the Seventh Session of the International Refugee Organization General Council entitled "The International Tracing Service. Brief Review of Its History and Activities,” March, 1961, 3; http://search.archives.jdc. org/notebook_ext.asp?item=2146841.

34 Ibid., 5.

35 Ibid. 


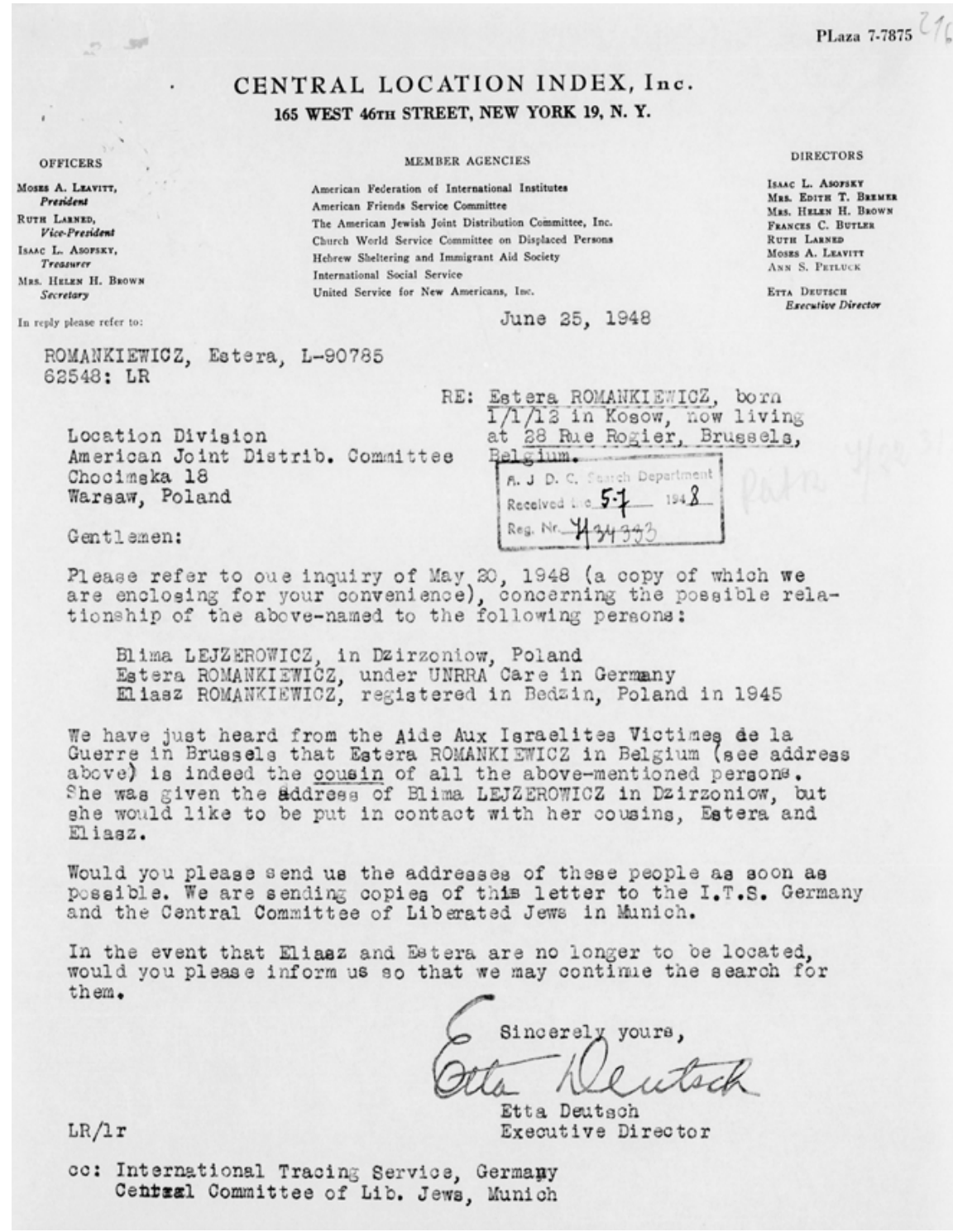

Fig. 14: Letter from Etta Deutsch, Central Location Index, to JDC Location Division, Warsaw, regarding relatives of Estera Romankiewicz, now living in Brussels, Belgium, 25.6.1948 (JDC Archives, Records of the Warsaw Office of the American Joint Distribution Committee, 19451949, folder \#1006; http://search.archives.jdc.org/notebook_ext.asp?item=2290048) 
Given the non-permanent character of the International Refugee Organization (IRO), the ITS was intended to be a temporary function for a 2 to 3 year period. Work would be organized so as to facilitate a future transfer of remaining tracing functions from the IRO to a more permanent body, as yet not determined.

Under Maurice Thudichum's leadership, a three-year plan was designed beginning in 1948 for the reorganization, consolidation and coordination of tracing work. The greatest results were attained in 1949 when the child service bureau was expanded. The ITS master card index expanded from 1,976,499 cards in January of 1948 to $10,538,358$ cards by the end of $1950 .{ }^{36}$

As of March 1950, individual tracing was ended, and responses to inquiries were based only on ITS information (and not sent to national tracing bureaus). From 1948 - 1950, the ITS handled 220,303 individual tracing requests from 100 countries. It was able to positively establish the fate of 26,797 individuals and tentatively establish the fate of a further 18,997. In addition, the records of tracing agencies that had ceased activity (such as the CLI and JDC tracing activities) were integrated into the files of the ITS. ${ }^{37}$

\section{JDC and the International Tracing Service}

In January 1948, Maurice Thudichum wrote to organizations involved with tracing services soliciting feedback. Etta Deutsch responded with a long letter describing the CLI; inquiring how JDC field offices could get maximum benefit from ITS services in cases where their local search is not successful; and asking what mechanism would be worked out with ITS local and central. Deutsch concluded that the CLI would be happy to cooperate and referred the ITS to JDC Overseas Headquarters in Paris to discuss these questions. ${ }^{38}$

By August 1948, JDC transferred the Berlin tracing records to the ITS and closed its Berlin location tracing office. ${ }^{39}$ The JDC Paris headquarters Emigration Service registration cards were shared with the ITS, as were lists of survivors and

36 Ibid., 7-16.

37 Ibid., 12.

38 JDC Archives, Records of the New York Office of the American Jewish Joint Distribution Committee, 1945-1954, folder \#ORG.431, Letter from Etta Deutsch to Mr. M. Thudichum, 12.1.1948; http://search.archives.jdc.org/notebook_ext.asp?item=2146882.

39 JDC Archives, Records of the Geneva Office of the American Jewish Joint Distribution Committee, 1945-1949, folder \#SM.940, memorandum from Dorothy Levy of Location Service, Paris to All Country Directors and Field Offices regarding Transfer of Location Service from Berlin, Paris, 12.8.1948; http://search.archives.jdc.org/notebook_ext.asp?item=2545627. 


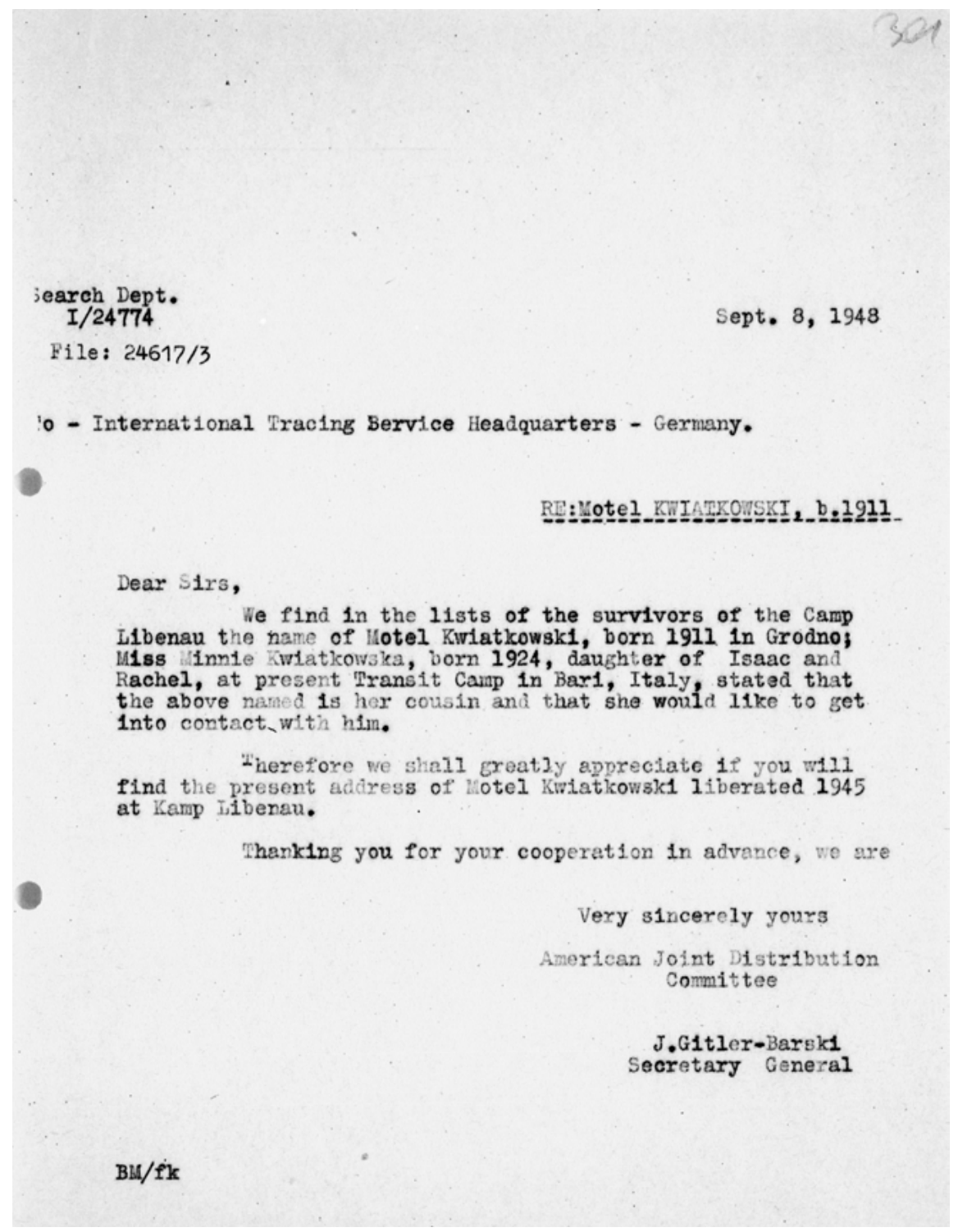

Fig. 15: Letter from J. Gitler-Barski, JDC Warsaw, to International Tracing Service Headquarters Germany, regarding an inquiry from someone in a transit camp in Bari, Italy, about her cousin, whose name appeared on a list of survivors, 8.9.1948 (JDC Archives, Records of the Warsaw Office of the American Joint Distribution Committee, folder \#618; http://search.archives.jdc.org/ notebook_ext.asp?item $=2231249$ ) 


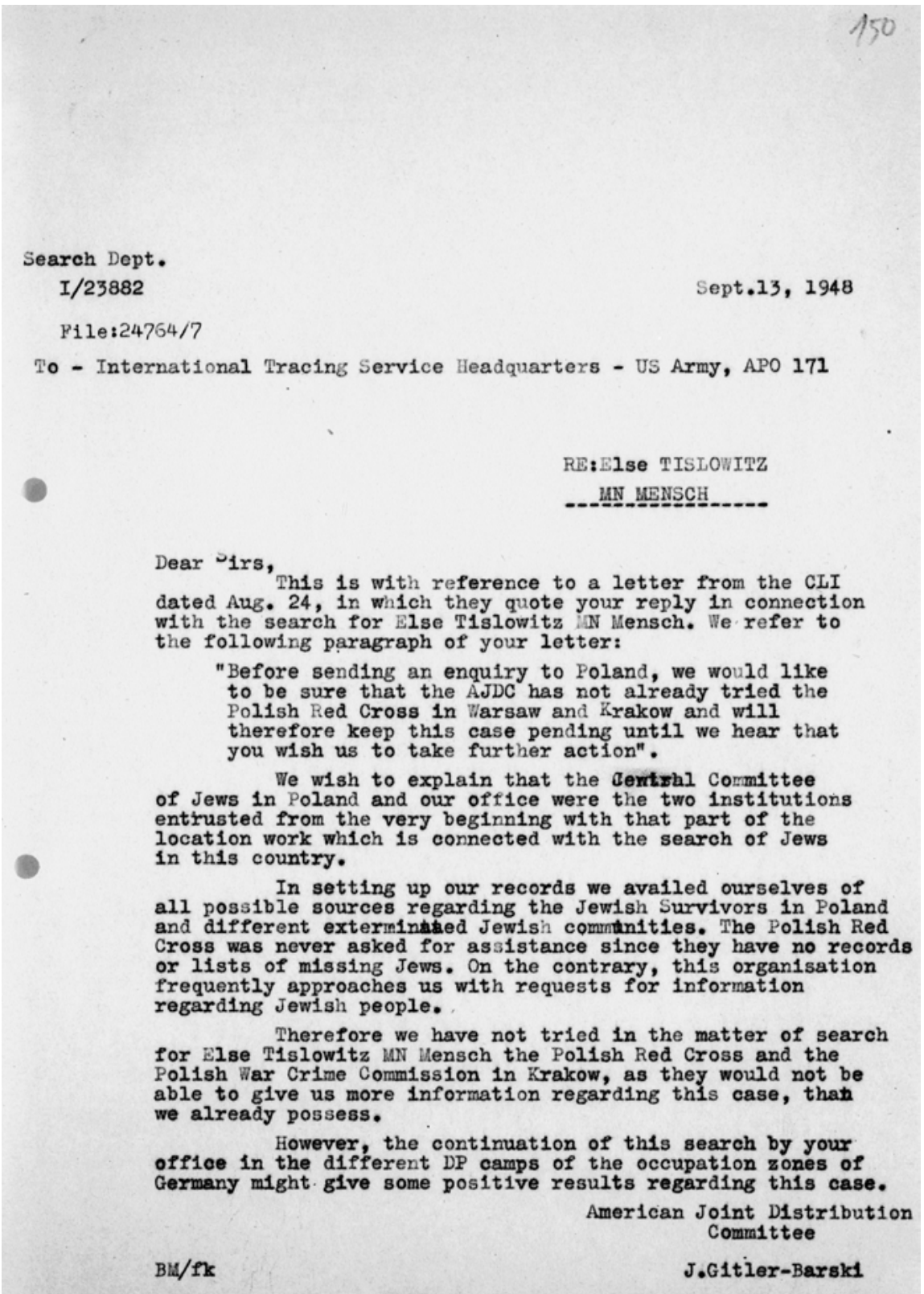

Fig. 16: Letter from J. Gitler-Barski, JDC Warsaw, to International Tracing Service Headquarters US Army, APO 171, regarding search procedures and location work in Poland, 13.9.1948 (JDC Archives, Records of the Warsaw Office of the American Joint Distribution Committee, folder \#618; http://search.archives.jdc.org/notebook_ext.asp?item=2231121) 
refugees and emigration lists from JDC local offices. In May 1949, the Central Location Index closed down in New York, and copies of the CLI registration cards were sent to the ITS.

\section{What Next?}

By the fall of 1949 the need to find a successor to handle ITS activities was urgent. The IRO was scheduled to terminate its activities in June 1950. The IRO General Council directed the Director-General to negotiate with interested governments or another international or inter-governmental body. Discussions took place with the International Committee of the Red Cross and yielded no positive result. The ITS was extended beyond June 30, 1950, on a reduced scale.

In March 1950, a decision was taken to enter into negotiations with the Allied High Commission in Germany with a view to arrange a takeover of the ITS from the IRO as early as possible before March 31, 1951. As of January 1, 1951, the Allied High Commission assumed responsibility and set up a working committee of British, French, and US representatives to negotiate the transfer. Operational responsibility was assumed as of April 1, 1951, with the IRO seconding tracing experts to the High Commission in Germany for 6 months. In April, 1951, the International Tracing Service was transferred from the International Refugee Organization (IRO) to the Allied High Command in Germany.

Intensive discussions then ensued among governments and NGOs on who would ultimately take over the ITS from the Allied Command in Germany. The JDC Archives includes extensive correspondence among Jewish organizations around the world trying to determine what the best alternatives for the auspices of the ITS would be for the Jewish community. The advantages and disadvantages of several options were discussed in this correspondence:

- Germany?

- International Committee of the Red Cross?

- UN High Commissioner for Refugees and DPs?

- US Library of Congress?

- The Claims Conference?

JDC archival records reflect the concerns raised by the various Jewish organizations, attempts to build a consensus preference, and consultation among organ- 
izations and with government officials..$^{40}$ These letters and memoranda highlight the concerns of the Jewish community, which focused on the following issues: - The preservation of the records needed to be assured.

- Nazi victims needed to turn to these records to prove entitlement to indemnification.

- Recognizing the role of the international governing body to be established, Jewish organizations were eager to ensure that Israel would be represented on the governing body.

- The attitudes of the Director of the body were critical, and the Jewish groups sought to ensure that the selected director would not be antisemitic or biased.

In 1955, an International Commission was established as the supervising body of the ITS, which remained in Arolsen, Germany. The International Commission today includes representatives from eleven member states, including Belgium, France, the Federal Republic of Germany, Greece, Israel, Italy, Luxembourg, the Netherlands, Poland, the United Kingdom, and the United States of America. The Federal Republic of Germany agreed to fund the operating costs of the ITS. In June 1955, Nicolas R. Burchhardt assumed the newly established position of ITS director. Burckhardt was affiliated with the ICRC which covered the ITS director's salary. Some of the concerns raised by Jewish groups came to haunt the ITS in subsequent years.

\section{Conclusion}

JDC Headquarters and its local offices around the world worked unstintingly to rescue and provide relief services for Jews fleeing Nazi Europe. The organization's prior experience and its relationships with local communities and with international and local agencies were advantages that helped JDC to galvanize aid where possible. JDC's prior experience with family tracing and search activities dating back to the First World War laid the groundwork for its extensive networking efforts in the Second World War era with US relatives of refugees in Europe who required assistance with affidavits and funds for visas and transportation. Likewise, these networking activities helped to reunite families in the US with their European relatives. JDC workers pursued these family search and tracing

40 For examples of this correspondence, see: JDC Archives, Records of the Geneva Office of the American Jewish Joint Distribution Committee, folders \#ORG.430 and \#ORG.431. 
activities with passion, expertise, empathy, and a sense of personal and communal mission, collaborating closely with the International Red Cross and with UNRRA Central Tracing Bureaus. Discussions that began in 1947 that envisioned the establishment of a more centralized International Tracing Service made Central Location Index and JDC leaders uneasy. They wondered whether a more distant and standardized ITS would have the knowledge, expertise, and sense of urgency that JDC local offices and the CLI staff had. Nevertheless, JDC leaders sought to cooperate with efforts to establish the IRO International Tracing Service and copied the ITS on all tracing correspondence. Beginning in August 1948, JDC began gradually closing down its tracing bureaus and transferring records to the ITS. In May 1949, the CLI ceased its operations.

The longer-term permanent fate and auspices of the International Tracing Service became political questions. In the decades following the establishment of the ITS in Arolsen, Germany, as an independent body with an international board, some of the concerns of Jewish agencies proved to be well-founded. 